\title{
Introduction to "The Dual-Agency Problem of Labor Union Pension Fund Shareholder Activism"
}

\author{
Victor G. Devinatz ${ }^{1}$
}

Published online: 2 September 2021

(C) The Author(s), under exclusive licence to Springer Science+Business Media, LLC, part of Springer Nature 2021

In 1984, Richard Freeman and James Medoff published a pathbreaking book in labor relations entitled What Do Unions Do? The two authors had presented the book's major arguments in a 1979 article, "The Two Faces of Unionism," appearing in The Public Interest. The volume and article established the exit/voice model of labor unionism, which represents the desirable face of unionism, in which the authors argue that voice processes, such as grievance procedures in labor contracts, increase economic efficiency through reducing employee turnover, while also boosting productivity and improving managerial performance. The undesirable face of unionism, however, the monopoly face, allows unions to increase wages above the competitive level through collective bargaining. However, according to the evidence presented by Freeman and Medoff, the benefits connected with the voice face of unionism predominates over the negative aspects of the monopoly face of unionism. Nevertheless, the labor union roles of providing representation through grievance procedures and engaging in collective bargaining are mutually compatible. As this issue's article in the "Perspectives" section indicates, labor unions, however, might sometimes adopt roles that conflict with each other.

In this well-written, interesting, timely and thought-provoking "Perspectives" Section article, Dr. Brandon Grant, Assistant Professor in the Department of Technology Leadership \& Innovation at Purdue University's Polytechnic Institute, discusses another labor union activity that has emerged over the last 20 years but has remained largely unexamined by industrial relations scholars. Professor Grant points out that labor unions have become active as shareholders in companies through their pension funds. He argues that labor unions as shareholders demonstrates that these organizations display behaviors "similar to other institutional investor groups consistent with the fiduciary responsibility that pension funds have to their constituents." Nevertheless, Professor Grant contends that labor unions may also participate in shareholder activism as a way of accomplishing objectives that unions desire to achieve since they serve as representative agents to their members. As such, Professor Grant argues that this dual agency is a quandary for labor unions because their obligation in one agency role conflicts with their responsibility under the other agency role.

Victor G. Devinatz

vgdevin@ilstu.edu

1 Department of Management \& Quantitative Methods, Illinois State University, Normal, IL 61790-5580, USA 
If any of the journal's readers are interested in responding to any essays published in the "Perspectives" Section or would like to write articles on any topics in the field of employee relations, please do not hesitate to contact me with your proposal. I welcome both practitioner-based and scholarly-based articles written from any one of a variety of theoretical perspectives. I hope that you enjoy this article and find it most illuminating.

Victor G. Devinatz, Editor of "Perspectives" Section

Department of Management \& Quantitative Methods

Illinois State University

Normal, Illinois 61790-5580

vgdevin@ilstu.edu

Publisher's Note Springer Nature remains neutral with regard to jurisdictional claims in published maps and institutional affiliations. 